\title{
Adding years to life: effect of avoidable mortality on life expectancy at birth
}

\author{
Fernando G Benavides, Rosa Orts, Santiago Perez
}

\begin{abstract}
Study objective-The aim was to determine the number of years that could be gained by preventing avoidable deaths.

Design-The study arose from the concept of avoidable causes of death and life expectancy at birth. Four abbreviated life tables were computed. The first included all causes of death; the second excluded all avoidable causes of death; the third and fourth excluded respectively primary and secondary avoidable causes of death.

Setting-Mortality and population data were taken from Mortality Statistics Offices in Valencia Region, Spain.

Main results-Life expectancy at birth (LEB) was 75.7 years. After removing all avoidable deaths, LEB increased by 1.74 years. This improvement is attributed to avoidable deaths by primary prevention (1.09 years) and avoidable death by secondary prevention ( 0.37 year).

Conclusions-According to these results the greatest improvement in LEB would be gained by primary prevention.
\end{abstract}

f Epidemiol Community Health 1992; 46: 394-395

Some of the main objectives of the "Health for all" WHO-Europe strategies are related to "adding years to life". This may be achieved by reducing deaths due to different diseases. Life expectancy has been suggested as the global indicator to measure the number of years that could be gained. ${ }^{1}$

Taking into account the concept of avoidable death, ${ }^{2-4}$ it is possible to determine how many years can be gained if these deaths had been actually prevented. Holland $e t a l^{5}$ have produced an operative list of avoidable causes of death, divided into two groups according to the impact of primary or secondary prevention procedures in these diseases: (1) primary prevention indicators (lung cancer, cirrhosis of the liver, and motor vehicle accidents); (2) secondary prevention indicators (tuberculosis, cervical cancer, Hodgkin's disease, chronic rheumatic heart disease, hypertensive and cerebrovascular disease, childhood respiratory disease, asthma, abdominal hernia, cholelithiasis and cholecystitis; and maternal and perinatal mortality).

The objective of this study was to determine how many years could be gained by preventing avoidable deaths in the Valencia Region (Spain) and to identify whether this gain can be attributed mainly to primary or to secondary prevention.
Methods

We included as avoidable deaths the causes and ages proposed by Holland, except for perinatal mortality, for which data were not available. Mortality and population data were taken from mortality statistics offices in Valencia Region in 1988. Abbreviated life tables constructed according to the method proposed by Chiang. ${ }^{6}$ The likelihood of death in each age group $(<1,1-5$, $6-10, \ldots .85$ years and more) was thus estimated.

Four abbreviated life tables were then computed. The first included all causes of death. In the second life table, we excluded all avoidable causes of death in the numerator of the age specific mortality rates which were used to compute the life table. The same procedure was used to produce the third and fourth life tables, but in these cases primary and secondary avoidable causes of death, respectively, were omitted in the computation of the tables.

\section{Results}

In 19882541 avoidable deaths took place in the Valencia Region $(7.5 \%$ of the total deaths). As shown in the table, life expectancy at birth was 75.7 years ( 72.5 for males and 78.9 for females). The life expectancy at birth would increase to $77 \cdot 2$ years (74.6 for males and 79.7 for females) if all avoidable deaths were removed. This improvement (two years for males and almost one year for females) could be broken down into one and a half years and half a year for males and females respectively attributable to primary prevention and almost half a year for both males and females attributable to secondary prevention.

\section{Discussion}

Although this approach to estimating the number of years which could be gained after removing avoidable deaths has not taken into account competitive mortality, ${ }^{7}$ we can assume that people who do not die from one of these causes will not die at these ages from other causes of death. Despite this limitation, the major advantage of this approach is its easy calculation and the fact that it is readily understandable.

Thus, according to current biomedical knowledge, one and a half years per person at birth could be gained in our region. The greater part of this gain would result from prevention. However these results do not mirror the current distribution of the health budget in our Region, where $99 \%$ is for medical care and only $1 \%$ for primary prevention. 8 This preference given to medical care as compared to public health could jeopardise the feasiblity of achieving the objectives related to 
"adding years to life" as stated by WHO-Europe, not just in our region but in other European regions with similar health budgets.

Life expectancy at birth ( $L E B$ ) and years of life gain (YLG) before and after removing avoidable deaths in the Valenica Region (Spain), 1988.

\begin{tabular}{|c|c|c|c|c|c|}
\hline & & Actual & $\begin{array}{l}\text { Without } \\
\text { all } \\
\text { avoidable } \\
\text { deaths }\end{array}$ & $\begin{array}{l}\text { Without } \\
\text { avoidable } \\
\text { deaths } \\
\text { by primary } \\
\text { prevention }\end{array}$ & $\begin{array}{l}\text { Without } \\
\text { avoidable } \\
\text { deaths } \\
\text { by secondary } \\
\text { prevention }\end{array}$ \\
\hline Male & $\begin{array}{l}\text { LEB } \\
\text { YLG }\end{array}$ & $72 \cdot 54$ & $\begin{array}{r}74.55 \\
2.01\end{array}$ & $\begin{array}{r}74 \cdot 15 \\
1.59\end{array}$ & $\begin{array}{r}72.92 \\
0.38\end{array}$ \\
\hline Female & $\begin{array}{l}\text { LEB } \\
\text { YLG }\end{array}$ & $78 \cdot 87$ & $\begin{array}{r}79 \cdot 67 \\
0.80\end{array}$ & $\begin{array}{r}79.33 \\
0.46\end{array}$ & $\begin{array}{r}79 \cdot 21 \\
0 \cdot 34\end{array}$ \\
\hline Total & $\begin{array}{l}\text { LEB } \\
\text { YLG }\end{array}$ & $75 \cdot 71$ & $\begin{array}{r}77 \cdot 18 \\
1 \cdot 47\end{array}$ & $\begin{array}{r}76.80 \\
1.09\end{array}$ & $\begin{array}{r}76.08 \\
0.37\end{array}$ \\
\hline
\end{tabular}

1 World Health Organization Targets for health for all. Copenhagen: WHO Regional Office for Europe, 1985.

2 Rustein D, Beremberg W, Chalmers T, Child C, Fishman A Perrin E. Measuring the quality of medical care. $N$ Engl $\mathscr{f}$ Med 1976; 294: 582-8.

3 Charlton JRH, Hartley RM, Silver R, Holland WW. Geographical variation in mortality from conditions Geographical variation in mortality from condition amenable to medical intervention ancet 1983; i: 691-6.

4 Charlton JRH, Velez R. Some international comparisons of mortality amenable to medical intervention. $B M \mathcal{F} 1986$ 292: 295-301.

5 Holland WW, ed. European Community atlas of avoidable death. Oxford: Oxford University Press, 1988.

6 Chiang CL. Introduction to stochastic process in biostatics. New York: John Wiley and Sons, 1986.

7 Arriaga EE. Measuring and explaining the change in life expectancies. Demography 1984; 21: 83-96.

8 Generalitat Valencia. Presupuestos 1990. Valencia; Concelleria d'Economia i Hisienda. 1989.

\section{Conditions in nineteenth century lodging houses}

Sir fohn Walsham thus exemplifies the descriptions he has received of the lodging-houses in Newcastle:-

"There is a considerable number of lodging-houses in Newcastle, some of the rooms of which are frequently occupied by from 15 to 20 persons each. In these houses the most deplorable scenes of profligacy and depravity are met with, both sexes being crowded together in a manner injurious to both health and morals.

"A medical gentleman told me, in Stockton, this morning, that in the common lodging-houses where travelling vagrants are frequently attacked by fever, \&c., and in many cases die, the beds are the very next night occupied by fresh inmates, who are of course infected with the same disorder."

And one of the relieving officers for the same town says:-

"I have frequently had occasion to complain to the magistrates against the lodging-houses taking in so many lodgers; but the law in this respect is so defective that they could render me no assistance. On a Sunday last July, I went to see a man (a travelling musician) who was very ill of the small-pox, and died a few days afterwards. The house contained four small rooms, and was situated in a back yard, in a very narrow, confined, dirty lane. There were 40 people in the house, and they were not all in that lodged there. Four months ago I went into a room in the same yard; the room was very dirty; it was 9 feet broad by 15 feet long, and contained four beds, in which slept two men, four women, and thirteen children. I found in one of the beds two children very ill of scarlet fever; in another, a child ill of the measles; in another, a child that had died of the measles the day before; and in a fourth, a woman and her infant, born two days before; and the only space between the four beds was occupied by a tinker, hard at work."

Report to Her Majesty's Principal Secretary of State for the Home Department, from the Poor Law Commissioners on an inquiry into the Sanitary Condition of the labouring population of Great Britain, 1842 